\title{
ROLES AND INDICATION OF POWER RELATIONS BETWEEN INDONESIAN MUSLIM LEADER AND THE AMERICAN CHRISTIANS IN RICHARD LEWIS' THE FLAME TREE
}

\author{
Rosyida Ekawati \\ Email: idasunyigono@gmail.com \\ Fakultas Ilmu Sosial dan Budaya Universitas Trunojoyo \\ Alamat Koresponden: Jalan Raya Telang PO Box 2 Kamal Bangkalan Madura
}

\begin{abstract}
Novel is sometimes more powerful than other types of literature and art, as such novels are directed to the widest possible audience. They are dramatic works which show interesting qualities by drawing the readers' interest. Novels also cultivate the imagination, contribute to and deepen the capacity for moral reflection. Novel about Indonesian Muslims, written by non-Indonesians, need to get more attention because the novel has the power to create the identity of Indonesian Muslims through its representation. The identity represented will be viewed not only by Indonesian Muslims but also by people all over the world. Critical Discourse Analysis (CDA) serves as the study's main theoretical foundation and Fairclough's Three-Dimensional Model of Discourse is used to analyze the roles of religious leaders and the indication of power relations between the Indonesian Muslim leader and the American Christians. Categorized data are analyzed predominantly using textual analysis, a qualitative method. Results reveal the roles of religious leader are significant in building the character of Indonesian Muslims. Further, power relations between the Indonesian Muslim leader and the American Christians are constructed by language and paralanguage used in their interaction and communication.
\end{abstract}

\section{Keywords}

Critical Discourse Analysis (CDA), Indonesian Muslims, Kiai

\section{Introduction}

Novels, by laying the claim of another story, can play a crucial role in public reasoning. They cultivate the imagination, contribute to and deepen the capacity for moral reflection. Novel is not a dream nor is it guesswork. It is imagining based on facts. Though other forms of art and literature would serve public discourse quite well, the novel is a living form and in fact still is the central morally serious yet popularly engaging fictional form in our culture.

One of the novels portraying Indonesian Muslims is Richard Lewis' The Flame Tree. It becomes interesting and important to be studied. It was written by an American author, representing Indonesian Muslims, particularly Muslims in Java. In the novel, the religious identities of the Javanese Muslims of Indonesia are reconstructed into a series of social typologies, often presented within the framework of hostility and terrorism.
Novels about Indonesian Muslims, written by nonIndonesians, need to get more attention because the novel has the power to create the identity of Indonesian Muslims through its representation. The identity represented will be viewed not only by Indonesian Muslims but also by people all over the world.

This study seeks to elucidate the roles of Indonesian Muslim religious leaders represented in the novel, and highlight indications of power revealed in the communication between the Indonesian Muslim leader and the American Christians 


\section{Conclusion}

From the findings of the study on the Critical Discourse Analysis (CDA) of the novel, the following conclusions can be drawn: Muslims religious leader plays a significant role in building the Muslim community in accordance with existing values in the society and laws. The Muslim leader still plays his role to serve as provider, protector, educator, and source of values in the society. As a language is not neutral, the langauge used by the Indonesian Muslim Leader and the American Christians represents the power relations among them.

\section{REFERENCES}

Allen, Graham. 2000. Intertextuality. London: Graham Allen.

Aragay, Mireia, ed. 2006: Books in Motion: Adaptation, Intertextuality, Authorship. Amsterdam and New York: Rodopi. 289pp. ISBN: 90-420-1885-2

Bakri, Masykuri. Ed. 2002. Metodologi Penelitian Kualitatif: Tinjauan Teoritis dan Praktis. Malang: Lembaga Penelitian Universitas Islam Malang collaborated with Visipress.

Chandler, Daniel. Semiotics for Beginners. <http://www.aber.ac.uk/media/Documents/S4B/semiotic.html>. $7 / 5 / 2011$

Chi, Feng-Ming. (1995). "EFL Readers and a Focus on Intertextuality”. Journal of Reading. Vol. 38, No. 8 (May, 1995). Pp. 638-644. International Reading Association.

Goodman, Y.M., Watson, D., and Burke C. 1987. Reading Miscue Inventory: Alternative Procedures. New York: Richard C. Owen.

Hartman, D.K. (1990). “The Intertextual Links of Readers Using Multiple Passages: A Postmodern/Semiotic/Cognitive View of Meaning Making”. In R. Ruddel, M. Ruddel, \& H. Singer (Eds.). Theoretical Models and Processes of Reading. Newark, Delware: International Reading Association.

http://www.jstor.org/stable/40032309

Kang, Dong-Ho, 1999. L2 Children's Reading Conceptions and Its Relationships with Intertextuality. www.eric.ad.gov/PDFS/ED430210.pdf. 7/11/2010.

Kristeva, Julia. (1986). The Kristeva Reader. New York: Columbia University Press.

Paech, Joachim. 2000. Artwork-Text-Medium. Step en route to Intermedialiti. Online in Internet: http://www.uni-konstanz.de/FuF/litWiss?Medien Wiss/texte/interm.html. 